\section{In Reply to Dr Hill}

To the Editor:

We thank Dr Hill for his letter to the editor ${ }^{1}$ regarding our recent publication, "A National Survey of Wilderness Medicine Curricula in the United States Emergency Medicine Residencies"2 and appreciate the opportunity to comment.

Indeed, a study evaluating wilderness medicine (WM) education was published in $2015,{ }^{3} 3$ y prior to our data collection. We reference that paper here not to draw it into any critique, but as a foundation for our work. Although the 2015 study does not specify the timing of actual data collection, the listing of 187 residencies used was based on a Society for Academic Emergency Medicine directory accessed in March of 2014. In the interim, emergency medicine residency program numbers grew by almost $30 \%$. We believe this rapid growth in residencies, rather than a specific timeframe, should be the indicator for reappraisal.

Although we too would have preferred a higher response rate, our response rate of $57 \%$ is comparable to that of the 2015 paper $(56 \%)$. No analysis of nonresponding programs was given in that study, so we cannot compare these points. Similarly, neither paper specifically defined WM educational content, and the model of the clinical practice of emergency medicine has not changed significantly between the 2013 and 2016 versions. $^{4,5}$ Although indeed "every program should be teaching WM to a degree," programs indicated that they did not teach any WM, so the interpretation of the terminology by respondents may have been similarly limited. As such, although our approaches did differ, we believe that our paper can be viewed as complementary to the 2015 study.

Lastly, we concur in our paper that categorizing programs by geography could have yielded additional insights, and we encourage the inclusion of these data in future studies.

We appreciate Dr Hill's statement that our study poses "more questions than answers" as an opportunity for further inquiry and look forward to contributing to the effort to cement excellent WM education in our residencies on a national level.

Katja Goldflam, MD

Ryan F. Coughlin, MD

A. Cotton Widdicombe, MD

David Della-Giustina, MD

Department of Emergency Medicine Yale School of Medicine

New Haven, Connecticut

\section{References}

1. Hill AD. More or less? Wilderness education in emergency medicine residencies. Wilderness Environ Med. 2021;32(4): 555-6.

2. Goldflam K, Coughlin RF, Widdicombe AC, DellaGiustina D. A national survey of wilderness medicine curricula in United States emergency medicine residencies. Wilderness Environ Med. 2021;32(2):187-91.

3. Aronstam EJ, Christensen ML, Williams MP, Overton DT. Wilderness medicine curricular content in emergency medicine residency programs. Wilderness Environ Med. 2015;26(4):577-9.

4. Counselman FL, Borenstein MA, Chisholm CD, Epter ML, Khandelwal S, Kraus CK, et al. The 2013 model of the clinical practice of emergency medicine. Acad Emerg Med. 2014;21(5):574-98.

5. Counselman FL, Babu K, Edens MA, Gorgas DL, Hobgood C, Marco CA, et al. The 2016 model of the clinical practice of emergency medicine. J Emerg Med. 2017;52(6):846-9.

\section{A Case of Splenic Injury Caused by a Blow from a Dolphin's Tail Fin}

To the Editor:

The common bottlenose dolphin, Tursiops truncatus, has a global distribution. The mammal weighs an average of 150 to $200 \mathrm{~kg}$ and reaches 2 to $4 \mathrm{~m}$ in length. ${ }^{1}$ Dolphins are characterized as high-speed swimmers, propelled by a powerful horizontal lunate tail fin consisting of 2 flukes, which play an important role in their swimming. ${ }^{2}$ They can leap in the air or stand out of the water using this tail fin. They are also intelligent creatures and able to learn tricks, perform in shows, or interact with humans after appropriate training. ${ }^{3}$ We herein report a case of splenic injury induced by a blow from a dolphin's tail fin.

A 12-y-old boy in a wetsuit was travelling through the water while holding the dorsal fin of a trained bottlenose dolphin in an aquarium. He had no remarkable personal or family medical history and was a tourist from Saitama, located near Tokyo. When he erroneously released the dorsal fin, he sustained a sharp blow to the left flank by the dolphin's tail fin. He acutely felt severe pain, but he returned to his hotel with his parents. He then experienced a generalized tonic clonic seizure of approximately $10 \mathrm{~s}$ in duration at $3 \mathrm{~h}$ after the injury. He vomited 5 times within $7 \mathrm{~h}$ after the seizure. These symptoms did not recur throughout the night or the following day. However, the flank pain did not improve. His parents called an ambulance, and he was transported to our hospital by a 
Table 1. Spleen organ injury scale-2018 revision ${ }^{4}$

\begin{tabular}{|c|c|}
\hline $\begin{array}{l}\text { AAST } \\
\text { Grade }\end{array}$ & $\begin{array}{l}\text { Imaging criteria (computed tomography } \\
\text { findings) }\end{array}$ \\
\hline I & $\begin{array}{l}\text { Subcapsular hematoma }<10 \% \text { surface area } \\
\text { Parenchymal laceration }<1 \mathrm{~cm} \text { depth } \\
\text { Capsular tear }\end{array}$ \\
\hline II & $\begin{array}{l}\text { Subcapsular hematoma } 10-50 \% \text { surface area; } \\
\text { intraparenchymal hematoma }<5 \mathrm{~cm} \\
\text { Parenchymal laceration } 1-3 \mathrm{~cm}\end{array}$ \\
\hline III & $\begin{array}{l}\text { Subcapsular hematoma }>50 \% \text { surface area; } \\
\text { ruptured subcapsular or intraparenchymal } \\
\text { hematoma } \geq 5 \mathrm{~cm} \\
\text { Parenchymal laceration }>3 \mathrm{~cm} \text { depth }\end{array}$ \\
\hline IV & $\begin{array}{l}\text { Any injury in the presence of a splenic } \\
\text { vascular injury or active bleeding confined } \\
\text { within splenic capsule }\end{array}$ \\
\hline & $\begin{array}{l}\text { Parenchymal laceration involving segmental or } \\
\text { hilar vessels producing }>25 \% \\
\text { devascularization }\end{array}$ \\
\hline V & $\begin{array}{l}\text { Any injury in the presence of splenic vascular } \\
\text { injury with active bleeding extending } \\
\text { beyond the spleen into the peritoneum } \\
\text { Shattered spleen }\end{array}$ \\
\hline
\end{tabular}

physician-staffed helicopter. Helicopter transportation was arranged owing to the distance needed to travel to arrive at the hospital; ground ambulance would take more than $90 \mathrm{~min}$, versus $15 \mathrm{~min}$ by helicopter.

On arrival, his level of alertness was Glasgow Coma Scale score of 14 (E3V5M6) with a blood pressure of 129/70 (normal range: 110-124/70-79) $\mathrm{mm} \mathrm{Hg}$, a heart rate of $109(55-85)$ beats $\mathrm{min}^{-1}$, a respiratory rate of 30 $(12-18)$ breaths $\cdot \mathrm{min}^{-1}$, and a percutaneous oxygen saturation of $97 \%$ on room air. The physical examination findings included only localized rebound tenderness in the right flank without skin lesions, contralateral to the side of the initial injury. The main results of a blood analysis were as follows: white blood cell count, $15,800 \cdot \mu \mathrm{L}^{-1}$ (normal 4000-10,700 $\mu \mathrm{L}^{-1}$ ); hemoglobin, $10.5 \mathrm{~g} \cdot \mathrm{dL}^{-1}$ (normal 12.7-15.7 $\mathrm{g} \cdot \mathrm{dL}^{-1}$ ); platelets, $31.0 \times 10^{4} \mu \mathrm{L}^{-1}$ (normal $18-44 \times 10^{4} \mu \mathrm{L}^{-1}$ ); aspartate aminotransferase, 29 $\mathrm{IU} \cdot \mathrm{L}^{-1}$ (normal $15-31 \mathrm{IU} \cdot \mathrm{L}^{-1}$ ); alanine aminotransferase, $10 \mathrm{IU} \cdot \mathrm{L}^{-1}$ (normal 9-32 IU $\cdot \mathrm{L}^{-1}$ ); blood urea nitrogen, 21.1 $\mathrm{mg} \cdot \mathrm{dL}^{-1}$ (normal $6.8-19.2 \mathrm{mg} \cdot \mathrm{dL}^{-1}$ ); and creatinine, 0.63 $\mathrm{mg} \cdot \mathrm{dL}^{-1}$ (normal $0.39-0.62 \mathrm{mg} \cdot \mathrm{dL}^{-1}$ ). An abdominal ultrasound revealed hyperechoic areas at Morrison's pouch, around the spleen, and at the rectovesical pouch. Enhanced computed tomography showed a grade III splenic laceration, according to the American Association for the Surgery of Trauma splenic injury scale (Table 1$),{ }^{4}$ with no findings of extravasation or pseudoaneurysm (Figure 1), as well as fluid retention of the small intestine in the right abdomen, probably due to the subileus state after splenic injury. He

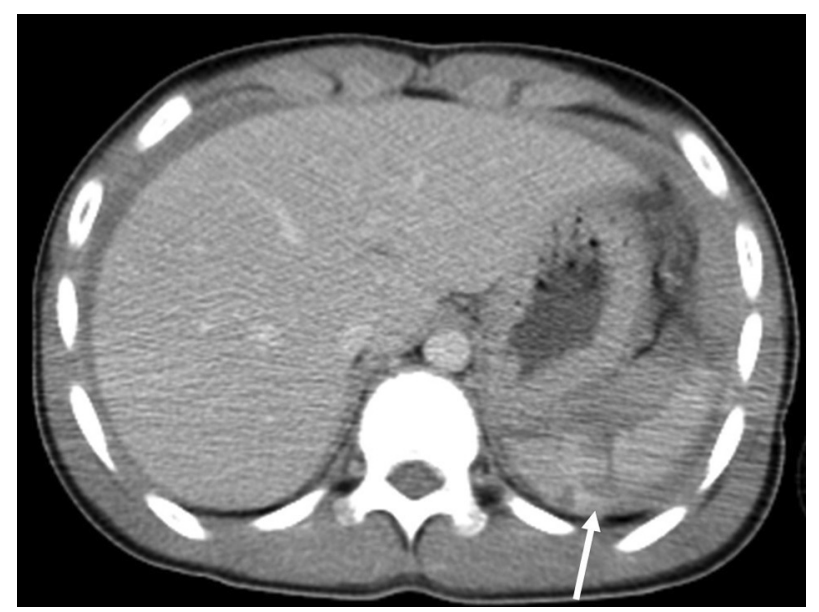

Figure 1. Findings of enhanced computed tomography on arrival. Computed tomography showed a grade of III (see arrow) according to the American Association for the Surgery of Trauma splenic injury scale.

was diagnosed as having an isolated splenic injury with a large amount of hemorrhaging in the intra-abdominal space, and he underwent angiography for embolization. However, the radiologists were unable to insert a catheter into the splenic artery, and the patient was admitted under observational status.

On Day 2, the patient's hemoglobin level dropped to $8.0 \mathrm{~g} \cdot \mathrm{dL}^{-1}$, and he received a transfusion of 2 units of red blood cells for fatigue. The patient tolerated the transfusion well. On Day 3, his hemoglobin level increased to $9.0 \mathrm{~g} \cdot \mathrm{dL}^{-1}$, and he began to eat and was initiated on an iron agent and acetaminophen. Subsequent contrastenhanced computed tomography on Days 4 and 7 revealed no significant changes, and the posttransfusion course was uneventful. An electroencephalogram was normal, and he was free from seizures during hospitalization, without the need for an anticonvulsant. The precise mechanism was unclear, but the cause of the convulsions might have been transient hypotension or some cranial damage. After the final computed tomography examination, his bedrest was finished. His hemoglobin level returned to $11.2 \mathrm{~g} \cdot \mathrm{dL}^{-1}$. On Day 12 , he was transported to a local hospital in Saitama for evaluation of late-presenting complications after splenic trauma, with a plan to return to school.

The patient in the present case underwent angiography for embolization of the splenic artery even though he had stable vital signs. The American Pediatric Surgical Association guidelines state that embolization should be performed only in patients with evidence of ongoing hemorrhaging. ${ }^{5}$ However, the results of a study comparing prophylactic splenic arterial embolization (pSAE) with surveillance and then embolization only if 
necessary (SURV) in a randomized clinical trial revealed significantly fewer splenic pseudoaneurysms and a shorter duration of hospitalization for adult patients in the pSAE group than for those in the SURV group. ${ }^{6}$ Accordingly, pSAE was performed in the present case.

Several newspaper articles have reported human injuries induced by dolphins. ${ }^{7-9}$ Dolphins can injure or kill humans by biting, attacking, hitting with their tails or snouts, or drowning by dragging humans underwater. During the literature review, the authors found a news report involving an encounter between 2 intoxicated tourists and a dolphin. The tourists grabbed the dolphin, rode it like a horse, and even attempted to insert an ice cream stick into its blowhole. The dolphin attacked the tourists. One of the tourists died as a result of internal organ damage sustained during the attack, and the second tourist sustained a broken rib and injuries to the head caused by blows from the animal's tail fin. ${ }^{9}$ Such potential risks based on historical accounts of human-dolphin interactions are described in a previous paper. $^{10}$

The present case was indeed an accident. However, dolphins can be dangerous animals, and caution may be necessary when humans interact with these creatures. There are many regulations protecting dolphins. We could find no regulations, guidelines, or protective measures in place to ensure the safety of humans when interacting with dolphins, suggesting no such measures have yet been established. ${ }^{10}$ In addition, there were few medical reports concerning dolphin-related injury. A further analysis with the accumulation of reports concerning dolphin-related injury will be necessary; such findings will function as the basis for establishing relevant regulations.

\section{Ryuji Takada, MD \\ Youichi Yanagawa, MD, PhD Ikuto Takeuchi, MD, PhD \\ Department of Acute Critical Care Medicine Shizuoka Hospital, Juntendo University Shizuoka, Japan}

\section{References}

1. Mizuguchi H, ed. Encyclopedia concerning whale and dolphin. Shinagawa, Tokyo: Britannica Japan; 1998:1-287. In Japanese.

2. Sun O, Morikawa H, Kobayashia S, Uedab K, Miyahara H, Nakashima M. Structure and mechanical properties on tail flukes of dolphin. J Aero Aqua Biomech. 2010;1:45-50.

3. Clegg ILK, Rödel HG, Cellier M, Vink D, Michaud I, Mercera B, et al. Schedule of human-controlled periods structures bottlenose dolphin (Tursiops truncatus) behavior in their free-time. J Comp Psychol. 2017;131(3):214-24.

4. Kozar RA, Crandall M, Shanmuganathan K, Zarzaur BL, Coburn M, Cribari C, et al. Organ injury scaling 2018 update: spleen, liver, and kidney. J Trauma Acute Care Surg. 2018;85(6):1119-22.

5. Gates RL, Price M, Cameron DB, Somme S, Ricca R, Oyetunji TA, et al. Non-operative management of solid organ injuries in children: An American pediatric surgical association outcomes and evidence based practice committee systematic review. J Pediatr Surg. 2019;54(8):1519-26.

6. Arvieux C, Frandon J, Tidadini F, Monnin-Bares V, Foote A, Dubuisson V, et al. Effect of prophylactic embolization on patients with blunt trauma at high risk of splenectomy: a randomized clinical trial. JAMA Surg. 2020;155(12):1102-11.

7. Broad WJ. Evidence puts dolphins in new light, as killers. The New York Times. 1999, July 6.

8. Malm S. Five swimmers rescued from dolphin attack after the animal slapped and jabbed them with its tail and nose off the coast of Ireland. Mail Online. 2014; Oct 2.

9. Buriham S. Banhista é morto por golfinho em SP. Folha de S.Paulo. 1994;Dec 9. In Portuguese.

10. Orams MB. Historical accounts of human-dolphin interaction and recent developments in wild dolphin based tourism in Australasia. Tourism Management. 1997;18(5):317-26.

\section{Medics Need the Wilderness as Much as It Needs Medics: A Letter in Reply to "Can't See the Wood for the Trees"}

\section{To the Editor:}

I write in reply to the fascinating letter by Robert Cussen published in this journal ${ }^{1}$ extolling the unique place of woods and trees within medicine and the ways in which we interpret this phenomenon. Although I enjoyed the whole piece, I found myself drawn particularly to his final statement. As a medical student revising for examinations myself, the assertion that we would be better off returning to the trees (or else losing ourselves in the wilderness in general) is one that resonates deeply.

The benefits of this reimmersion are multiple. Although the superiority of outdoor exercise over equivalent indoor exertion is disputed, ${ }^{2}$ exercise is certainly beneficial to mood, health, and focus ${ }^{3}$ and is something that is implicitly linked to the very act of finding oneself in a wilderness environment, far from easy comforts and motorized transportation. Furthermore, research into the effects of nature itself on our ability to focus profound directed attention, and on our mood, highlights a link between the range of softhard fascination ${ }^{4}$ evoked within these wild environments 